\title{
Geology
}

\section{Thermochronological evidence for the movement of the Ailao Shan-Red River shear zone: A perspective from Vietnam}

Pei-Ling Wang, Ching-Hua Lo, Tung-Yi Lee, Sun-Lin Chung, Ching-Ying Lan and Nguyen Trong Yem

Geology 1998;26;887-890

doi: 10.1130/0091-7613(1998)026<0887:TEFTMO>2.3.CO;2

\section{Email alerting services}

Subscribe

Permission request click www.gsapubs.org/cgi/alerts to receive free e-mail alerts when new articles cite this article

click www.gsapubs.org/subscriptions/ to subscribe to Geology

click http://www.geosociety.org/pubs/copyrt.htm\#gsa to contact GSA

Copyright not claimed on content prepared wholly by U.S. government employees within scope of their employment. Individual scientists are hereby granted permission, without fees or further requests to GSA, to use a single figure, a single table, and/or a brief paragraph of text in subsequent works and to make unlimited copies of items in GSA's journals for noncommercial use in classrooms to further education and science. This file may not be posted to any Web site, but authors may post the abstracts only of their articles on their own or their organization's Web site providing the posting includes a reference to the article's full citation. GSA provides this and other forums for the presentation of diverse opinions and positions by scientists worldwide, regardless of their race, citizenship, gender, religion, or political viewpoint. Opinions presented in this publication do not reflect official positions of the Society.

\section{Notes}




\title{
Thermochronological evidence for the movement of the Ailao Shan-Red River shear zone: A perspective from Vietnam
}

\author{
$\left.\begin{array}{l}\text { Pei-Ling Wang* } \\ \text { Ching-Hua Lo }\end{array}\right]$ Department of Geology, National Taiwan University, Taipei, Taiwan \\ Tung-Yi Lee Department of Earth Sciences, National Taiwan Normal University, Taipei, Taiwan \\ Sun-Lin Chung Department of Geology, National Taiwan University, Taipei, Taiwan \\ Ching-Ying Lan Institute of Earth Sciences, Academia Sinica, Taipei, Taiwan \\ Nguyen Trong Yem Institute of Geological Sciences, National Center for Natural Sciences and Technology, Hanoi, Vietnam
}

\begin{abstract}
In order to explore the timing of strike-slip movement along the Ailao Shan-Red River shear zone, an ${ }^{40} \mathrm{Ar} /{ }^{39} \mathrm{Ar}$ thermochronological study of the Day Nui Con Voi metamorphic massif in northern Vietnam was undertaken. The massif, exposed in the southeastern segment of the Ailao Shan-Red River shear zone, reveals a rapid cooling in the early Miocene (25-21 Ma) after a very slow cooling ca. 34-25 Ma. The slow cooling period most likely resulted from a geothermal perturbation in the lithosphere owing to the late Paleogene (40-30 Ma) extension in eastern Tibet and western Yunnan, China. The rapid cooling, consistent with evidence of a wider rapid cooling span from 27 to 17 Ma compiled from the entire Ailao Shan-Red River shear zone, constrains the duration of left-lateral shearing, which eventually offset Indochina from South China by about $600 \mathrm{~km}$. The time constraints we have established reinforce the argument that the onset of the Ailao Shan-Red River shear zone postdates the opening of the South China Sea that began ca. 30 Ma. This result highlights the necessity for reevaluating the Cenozoic tectonic models of Southeast Asia.
\end{abstract}

\section{INTRODUCTION}

The Ailao Shan-Red River shear zone is the most significant geologic discontinuity in Southeast Asia (Fig. 1) and has been repeatedly advocated as an important boundary accommodating the convergence of India and Asia since early Cenozoic (e.g., Tapponnier et al., 1982, 1990). On the basis of stratigraphic and structural correlations, the left-lateral movement along the Ailao Shan-Red River shear zone occurred from 35 to $17 \mathrm{Ma}$, resulting in an offset of $700 \pm 200 \mathrm{~km}$ (for review, see Leloup et al., 1995). The resultant southeastward displacement of Indochina relative to South China, termed continental extrusion (Tapponnier et al., 1982), has been widely considered to be responsible for the opening of the South China Sea (e.g., Tapponnier et al., 1982, 1990; Peltzer and Tapponnier, 1988; Briais et al., 1993). Previous thermochronological studies suggested that the onset of extension might have propagated southeastward at a rate of $\sim 4.5 \mathrm{~cm} / \mathrm{yr}$ (for review, see Harrison et al., 1996). However, this conclusion was drawn mainly on the basis of data collected from the metamorphic massifs in southwestern Yunnan, China (e.g., the Diancang Shan and the Ailao Shan). Only a few studies (Leloup et al., 1995; Harrison et al., 1996) have partially investigated the Day Nui Con Voi metamorphic massif in northern Vietnam (Fig. 1).

*Present address: Institute of Earth Sciences, Academia Sinica, Taipei, Taiwan.

†Corresponding author. E-mail: loch@ccms.ntu. edu.tw.
On the basis of correlations with different magmatic rock suites, Chung et al. (1997) argued that the sinistral displacement along the Ailao ShanRed River shear zone approximated $600 \mathrm{~km}$. One piece of magmatic evidence, the late Paleogene (40-30 Ma) potassic rocks in western Yunnan and eastern Tibet, led them to suggest that the shearing was active only after ca. $30 \mathrm{Ma}$ and was preceded by an intraplate extension. The extension, along with sea-floor spreading in the South China Sea that commenced ca. $30 \mathrm{Ma}$, served as two endpoints for the initiation of the Ailao Shan-Red River shear zone (Chung et al., 1997). This view is different from the previously proposed continental extrusion model of Tapponnier et al. (1982). In this paper, a thermochronological study of metamorphic rocks from the Day Nui Con Voi massif, northern Vietnam, is presented. The results here show that motion along the Ailao ShanRed River shear zone occurred mainly from 25 to $21 \mathrm{Ma}$. This, in turn, supports the argument by Chung et al. (1997) and provides valuable insight to the geologic evolution of Southeast Asia after the India-Asia collision.

\section{GEOLOGIC SETTING}

The Day Nui Con Voi metamorphic massif is located in the southeastern part of the Ailao Shan-Red River shear zone (Fig. 1) and is bounded by the Song Hong fault in the south and the Song Chay fault in the north (General Geological Department, 1973). Both faults appear as high-angle, right-lateral slip faults having normal components on the margin of the metamorphic massif. Several Tertiary extensional basins, surrounded by Paleozoic and Mesozoic sequences, developed along the margin of the shear zone. Toward the southeast, the shear zone is gradually submerged and then covered by thick Quaternary sediments that compose the Red River delta. The entire fault system is generally believed to have resulted from large-scale, left-lateral movement during mid-Tertiary time as a response to the India-Asia collision. A recent reactivation has sheared right-laterally since the early Pliocene (Allen et al., 1984; Leloup et al., 1995). Similar to its counterparts in Yunnan, southwestern China (i.e., Xuelong Shan, Diancang Shan, and Ailao Shan; Fig. 1), the Day Nui Con Voi massif consists mainly of high-grade metamorphic rocks (mylonitic Middle Proterozoic gneisses and amphibolites) that extend about $300 \mathrm{~km}$ in length and have a width of 10-15 km along the Red River. Most gneisses and amphibolites show a well-defined foliation, striking subparallel to the shear zone. Mainly on the basis of petrological data from the Ailao Shan region, the peak metamorphic conditions in the Ailao Shan-Red River shear zone have been estimated to be as high as $710 \pm 70{ }^{\circ} \mathrm{C}$ and $\sim 7$ kbar (Leloup and Kienast, 1993). The metamorphic grade is somewhat lower in the Diancang Shan section (Leloup et al., 1993).

\section{${ }^{40} \mathrm{Ar} /{ }^{39} \mathrm{Ar}$ DATING RESULTS AND INTERPRETATION}

Gneiss, amphibolite, pegmatite, and leucogranite samples were collected from five localities in the Day Nui Con Voi metamorphic massif, northern Vietnam (Fig. 1). The latter two rock types occur as dikes that crosscut or develop along the foliation of the gneisses and hence are regarded as products of the mid-Tertiary shear movement (Tapponnier et al., 1990). Handpicked mineral separates of amphibole, muscovite, biotite, and $\mathrm{K}$-feldspar from various rocks were analyzed using the ${ }^{40} \mathrm{Ar} /{ }^{39} \mathrm{Ar}$ step-heating technique at National Taiwan University. Ages were calculated relative to LP-6 biotite $(127.7 \pm 1.4 \mathrm{Ma})$ (Odin et al., 1982). Results of ${ }^{40} \mathrm{Ar} /{ }^{39} \mathrm{Ar}$ analyses are plotted in age spectrum diagrams (Fig. 1). Furthermore, ${ }^{36} \mathrm{Ar} /{ }^{40} \mathrm{Ar}$ vs. ${ }^{39} \mathrm{Ar} /{ }^{40} \mathrm{Ar}$ isotope correlation diagrams were also plotted to examine the possible

Data Repository item 9883 contains additional material related to this article. 


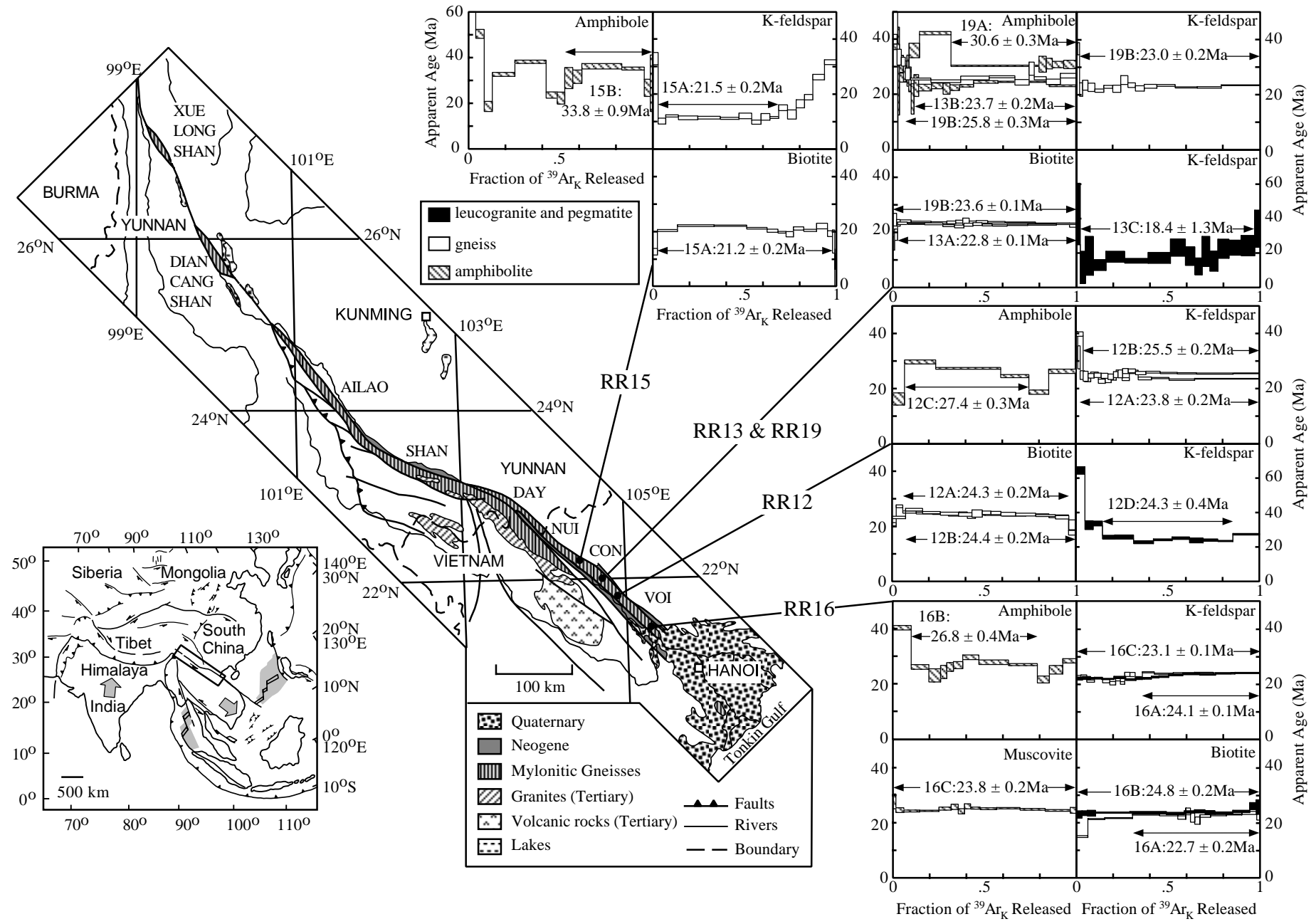

Figure 1. Simplified geologic map (after Harrison et al., 1996) with sample localities and age spectra for samples from Day Nui Con Voi massif, northern Vietnam. ${ }^{40} \mathrm{Ar} /{ }^{39} \mathrm{Ar}$ apparent ages were calculated on basis of $\mathrm{J}$ values obtained from analyses of LP-6 biotite having K-Ar age of 127.7 $\pm 1.4 \mathrm{Ma}$ (Odin et al., 1982). Detailed experimental procedures and age calculations were given by Lo and Lee (1994). Boxes for each step extend vertically to $\pm 1 \sigma$.

disturbances of argon isotopic systems. All ${ }^{40} \mathrm{Ar} /{ }^{39} \mathrm{Ar}$ dates in the discussion are plateau dates that were calculated from the sum total gas from those steps with dates within $2 \sigma$ (Tables 1 and 2 ). ${ }^{1}$

As shown in Figure 1, almost all the age spectra display a fairly flat profile. Although several $\mathrm{K}$-feldspars and amphiboles show anomalous dates at low- and/or high-temperature steps, perhaps due to the outgassing of impurities, these samples still yield acceptable plateau dates having ${ }^{39} \mathrm{Ar}$ gas proportions greater than $48 \%$. Their plateau dates agree well with intercept dates in the isotope correlation diagrams (Table 1). Their ${ }^{40} \mathrm{Ar} /{ }^{36} \mathrm{Ar}$ intercept values obtained from regressions are not significantly different from the atmospheric composition $\left({ }^{40} \mathrm{Ar} /{ }^{36} \mathrm{Ar}=295.5\right)$.

The plateau dates of amphiboles vary from 23.7 to $33.8 \mathrm{Ma}$ (Fig. 1). Even for those from the same outcrop, there is a significant difference in

${ }^{1}$ GSA Data Repository item 9883, Tables 1 and 2, detailed ${ }^{40} \mathrm{Ar} /{ }^{39} \mathrm{Ar}$ data, is available on request from Documents Secretary, GSA, P.O. Box 9140, Boulder, CO 80301. E-mail: editing@geosociety.org. amphibole dates from gneiss and associated amphibolite samples. This may result from different argon closure temperatures owing to different chemical compositions between amphiboles in various rock types (Onstott and Peacock, 1987). In contrast, all micas yield uniform plateau dates from 21.2 to $24.8 \mathrm{Ma}$. K-feldspars yield a range of 18.4 to $24.3 \mathrm{Ma}$ that is slightly younger than micas and amphiboles. We note here that overall mineral dates from pegmatites and leucogranites (Fig. 1) are consistent with, or younger than, the fast cooling age span estimated from the coexisting metamorphic rocks (Fig. 2).

\section{EXHUMATION OF THE METAMORPHIC MASSIFS}

The metamorphic massifs in the Ailao Shan-Red River shear zone were exhumed as a consequence of the left-lateral shearing movement (Tapponnier et al., 1990; Harrison et al., 1992, 1996; Leloup et al., 1993, 1995). Along with the radiometric dating on pegmatitic and leucogranitic veins (Schärer et al., 1990, 1994), thermochronological studies on the metamorphic rocks have provided important time constraints regarding the metamorphic exhumation and sinistral displacement (e.g., Harrison et al., 1992, 1996; Leloup et al., 1993). In general, the Ar closure temperatures for all minerals analyzed in this study are significantly lower than the peak metamorphic temperatures of the Ailao ShanRed River shear zone (Leloup and Kienast, 1993; Leloup et al., 1993). This leads us to interpret the ${ }^{40} \mathrm{Ar} /{ }^{39} \mathrm{Ar}$ dates we obtained as recording the time for these rocks to cool through their closure temperatures during exhumation. Therefore, with suitable diffusion parameters, the closure temperatures for amphiboles and micas are calculated according to Dodson's closure temperature scheme (Dodson, 1973) and then used to construct cooling paths (Fig. 2). Following the multidomain diffusion model (Lovera et al., 1991), the cooling, and hence exhumation, history of the metamorphic massif can be further constrained.

Figure 2 shows that the Day Nui Con Voi metamorphic massif underwent a high-temperature stage around $500{ }^{\circ} \mathrm{C}$ from 34 to $25 \mathrm{Ma}$, and then cooled rapidly ca. 25 to $21 \mathrm{Ma}$. In addition, 


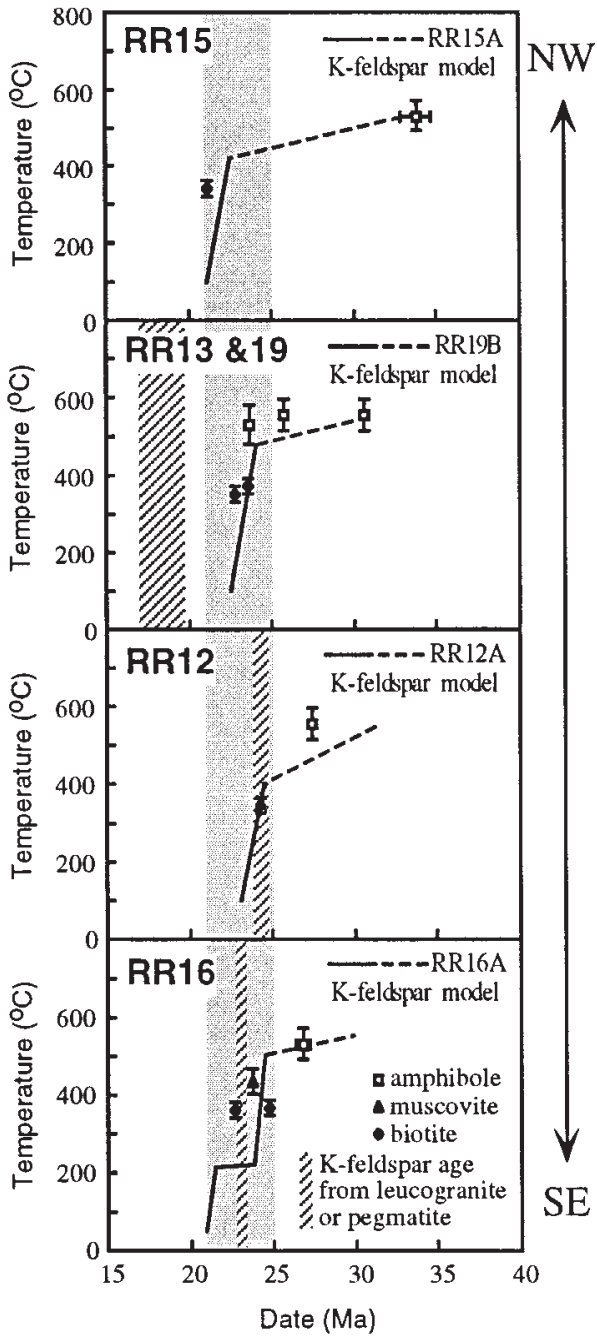

Figure 2. Cooling paths of samples from Day Nui Con Voi metamorphic massif. Calculations of closure temperatures for amphiboles and micas were done using suitable argon diffusion parameters (Onstott et al., 1989, and references therein), and half of grain size as diffusion dimension. Continuous cooling curves from K-feldspar ${ }^{40} \mathrm{Ar} /{ }^{39} \mathrm{Ar}$ analyses were obtained from experimental data using multidiffusion-domain hypothesis (Lovera et al., 1991). Age spans for associated pegmatites and leucogranites are also shown by hachured patterns.

samples from the southeastern part were exhumed and cooled earlier than those from the northwestern part, demonstrating a northwestward-younging trend for the fast cooling stage (Fig. 2). Assuming that cooling rate changes are due to the onset of shearing, the northwestward propagation rate of the exhumation front passing through the $400{ }^{\circ} \mathrm{C}$ isotherm, caused by the southeastward shearing movement, is estimated to be around $5 \mathrm{~cm} / \mathrm{yr}$. It is consistent with that estimated by Harrison et al. (1996) $(\sim 4.5 \mathrm{~cm} / \mathrm{yr})$ on the basis of results from the Ailao Shan massif. Comparing thermochronological data available from the entire Ailao Shan-Red River shear zone (Fig. 3), it is possible to further infer that there was no sig-

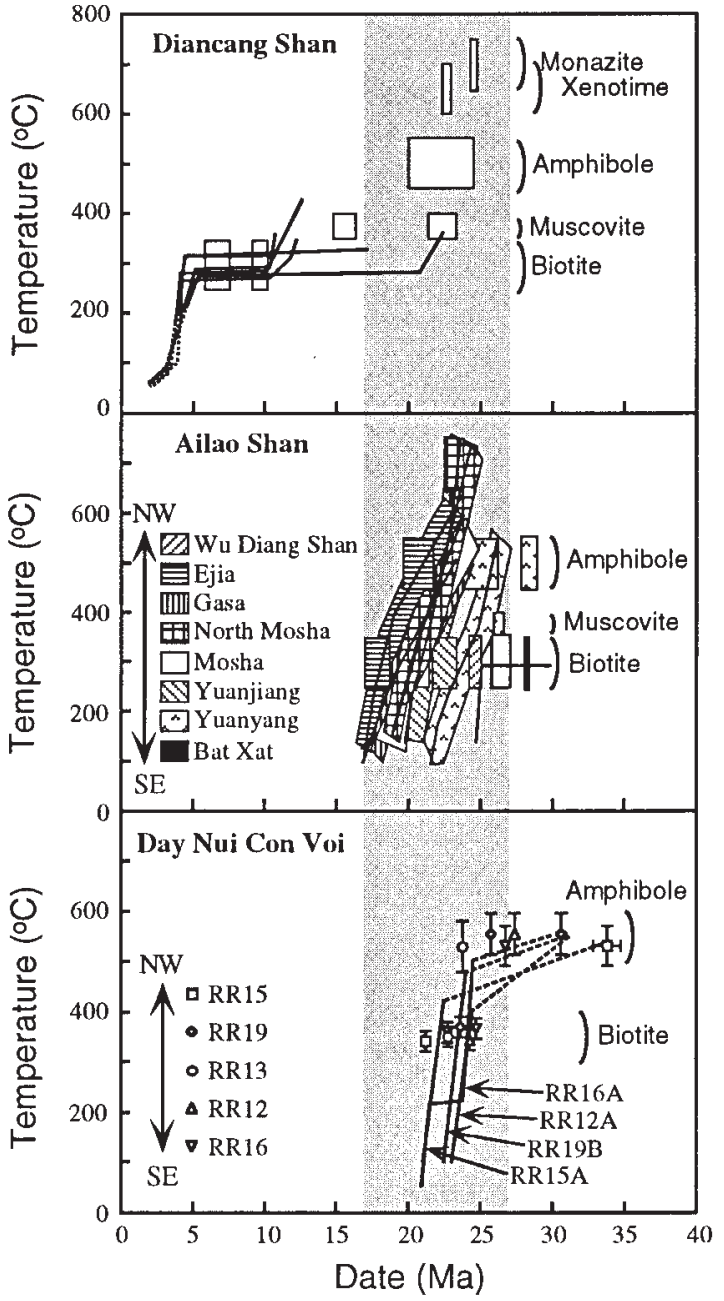

Figure 3. Compilation of thermochronological data for metamorphic massifs in Ailao Shan-Red River shear zone. Data are from Leloup et al. (1993) and Harrison et al. (1996) for Ailao Shan and Diancang Shan regions, and from this study for Day Nui Con Voi massif. nificant exhumation event recorded prior to $27 \mathrm{Ma}$ in the metamorphic massifs. After ca. $27 \mathrm{Ma}$, however, a pronounced rapid cooling took place from the Day Nui Con Voi through Ailao Shan to the Diancang Shan regions.

A careful examination of the cooling paths indicates that each segment in the Ailao ShanRed River shear zone exhibits somewhat different temperature ranges, exhumation durations, and cooling rates. Within the Day Nui Con Voi and Ailao Shan massifs, the exhumation front propagated northwestward at similar rates. However, the northwestward-younging trend is not reported in the Diancang Shan massif (Fig. 3). This observation has been explained as a result of diachronous initiation of transtension along the shear zone (Harrison et al., 1996). Based on all available data, we suggest that each massif has had its own response to the left-lateral shearing movement. Both the Ailao Shan and Day Nui Con Voi massifs had been exhumed from depths corresponding to about 700 and $500{ }^{\circ} \mathrm{C}$, respectively, to nearsurface levels prior to $17 \mathrm{Ma}$, as inferred from the K-feldspar ages. However, the Diancang Shan had not exhumed to the surface until ca. $5 \mathrm{Ma}$ (Fig. 3). After a tectonically quiescent period between ca. 17 and $5 \mathrm{Ma}$ within the entire shear zone, the Diancang Shan massif underwent a rapid cooling due to active normal faulting with a right-lateral component (Leloup et al., 1993). Overall, owing to the left-lateral shearing, the metamorphic massifs in the Ailao Shan-Red River shear zone were exhumed rapidly to various levels from ca. 27 to $17 \mathrm{Ma}$. The rapid cooling, likewise, began slightly earlier in the southeastern part of each metamorphic massif and propagated gradually to the northwest through time.

\section{EXTENSION PRIOR TO EXTRUSION}

Our ${ }^{40} \mathrm{Ar} /{ }^{39} \mathrm{Ar}$ thermochronological results demonstrate that the Day Nui Con Voi metamorphic massif underwent two stages of thermal evolution, i.e., a very slow cooling around $\sim 500{ }^{\circ} \mathrm{C}$ from ca. 34 to $25 \mathrm{Ma}$ and rapid cooling from ca. 25 to $21 \mathrm{Ma}$ (Fig. 2). The latter, together with a wider rapid cooling age period from ca. 27 to $17 \mathrm{Ma}$, recorded in the entire Ailao Shan-Red River shear zone, provides a straightforward time constraint on the left-lateral displacement of the shear zone. Furthermore, no rapid cooling older than ca. $27 \mathrm{Ma}$ has been observed in the metamorphic massifs. Before ca. $27 \mathrm{Ma}$, these highgrade metamorphic rocks were still residing in lower crustal levels at relatively high temperatures 
(down to $\sim 7$ kbar and $710 \pm 70{ }^{\circ} \mathrm{C}$; Leloup and Kienast, 1993). We interpret such a geothermal structure as a consequence of a late Paleogene intraplate extension that took place in eastern Tibet and western Yunnan and resulted in widespread potassic magmatism (Chung et al., 1997). The extension, probably caused by the removal of thickened lithosphere around eastern Tibet, might have been associated with a significant perturbation of geothermal structure in the lithosphere owing to replacement of the basal lithospheric mantle by a hotter and lighter asthenosphere (Platt and England, 1993). This study confirms the notion of Chung et al. (1997) that continental extrusion along the Ailao Shan-Red River shear zone was preceded by an intraplate extension in eastern Tibet and western Yunnan.

The collision of India with Asia since early Cenozoic time has been generally accepted as one of the most important processes in the Cenozoic tectonic evolution of East Asia. The resultant strike-slip movement along the Ailao Shan-Red River shear zone, for example, has been widely regarded as the key process responsible for opening the South China Sea (cf. Leloup et al., 1995) and for shaping Southeast Asia (e.g., Lee and Lawver, 1995). Pioneered by Tapponnier et al. (1982), there have been many investigations of this shear zone and, as summarized by Leloup et al. (1995), a general consensus has been that the shearing was active between 35 and $17 \mathrm{Ma}$. This time span is nearly identical with that of the sea-floor spreading of the South China Sea (ca. 30-16 Ma; Taylor and Hayes, 1983; Briais et al., 1993; Cande and Kent, 1995), and is thus consistent with the continental extrusion model, which advocates a displacement of Indochina relative to South China to initiate the opening of the South China Sea (cf. Tapponnier et al., 1982). Chung et al. (1997), however, argued against this scenario and proposed that the shearing could have begun only after ca. $30 \mathrm{Ma}$, because the high-K volcanic rocks would imply an intraplate extensional setting in this area in the late Paleogene time. The time constraints for the movement of the Ailao Shan-Red River shear zone provided by this study (27-17 Ma) reinforce the suggestion of Chung et al. (1997) and confirm that the Ailao Shan-Red River shear zone was actually initiated later than the onset of South China Sea opening. Furthermore, these findings also raise questions concerning the recognition of the Cenozoic tectonic evolution in Southeast Asia. The collision-extrusion model and the interactions among all relevant plates in this region need further examination and reevaluation.

\section{ACKNOWLEDGMENTS}

We thank D. V. Toan, T. V. Thang, H. H. Thanh, T. T. Hoa, and J.-C. Lee for help with field work in Vietnam, and O. M. Lovera for providing the multidiffusiondomain modeling program. We also thank G. S. Odin for providing a split of the LP-6 Biotite standard. M. Flower, T. C. Onstott, and P. R. Renne are thanked for constructive reviews. Supported by a grant from the
National Science Council (NSC87-2116-M-002020-Y), Taiwan, Republic of China.

\section{REFERENCES CITED}

Allen, C. R., Gillespie, A. R., Yuan, H., Sieh, K. E., Buchun, Z., and Chengnan, Z., 1984, Red River associated faults, Yunnan Province, China: Quaternary geology, slip rates, and seismic hazard: Geological Society of American Bulletin, v. 95, p. 686-700.

Briais, A., Patriat, P., and Tapponnier, P., 1993, Updated interpretation of magnetic anomalies and seafloor spreading stages in the South China Sea: Implications for the Tertiary tectonics of Southeast Asia: Journal of Geophysical Research, v. 98, p. 6299-6328.

Cande, S. C., and Kent, D. V., 1995, Revised calibration of the geomagnetic polarity timescale for the Late Cretaceous and Cenozoic: Journal of Geophysical Research, v. 100, p. 6093-6095.

Chung, S.-L., Lee, T.-Y., Lo, C.-H., Wang, P.-L., Chen, C.-Y., Yem, N. T., Hoa, T. T., and Genyao, W., 1997, Intraplate extension prior to continental extrusion along the Ailao Shan-Red River shear zone: Geology, v. 25, p. 311-314.

Dodson, M. H., 1973, Closure temperature in cooling geochronological and petrological systems: Contributions to Mineralogy and Petrology, v. 40, p. 259-274.

General Geological Department, 1973, Geological map of Vietnam (The northern part): Hanoi, General Geological Department, scale 1:1000000.

Harrison, T. M., Chen, W., Leloup, P. H., Ryerson, F. J., and Tapponnier, P., 1992, An early Miocene transition in deformation regime within the Red River fault zone, Yunnan, and its significance for IndoAsian tectonics: Journal of Geophysical Research, v. 97, p. 7159-7182.

Harrison, T. M., Leloup, P. H., Ryerson, F. J., Tapponnier, P., Lacassin, R., and Wenji, C., 1996, Diachronous initiation of transtension along the Ailao Shan-Red River shear zone, Yunnan and Vietnam, in Yin, A., and Harrison, T. M., eds., The tectonic evolution of Asia: New York, Cambridge University Press, p. 205-226.

Lee, T.-Y., and Lawver, L. A., 1995, Cenozoic plate reconstruction of Southeast Asia: Tectonophysics, v. 251, p. 85-138.

Leloup, P. H., and Kienast, J.-R., 1993, High-temperature metamorphism in a major strike-slip shear zone: The Ailao Shan-Red River, People's Republic of China: Earth and Planetary Science Letters, v. 118, p. 213-234.

Leloup, P. H., Harrison, M., Ryerson, F. J., Chen, W., Li, Q., Tapponnier, P., and Lacassin, R., 1993, Structural, petrological, and thermal evolution of a Tertiary strike-slip shear zone, Diancang Shan, Yunnan: Journal of Geophysical Research, v. 98, p. 6715-6743.

Leloup, P. H., Lacassin, R., Tapponnier, P., Schärer, U., Dalai, Z., Xiaohan, L., Liangshang, Z., Shaocheng, J., and Trinh, P. T., 1995, The Ailao ShanRed River shear zone (Yunnan, China), Tertiary transform boundary of Indochina: Tectonophysics, v. 251, p. 3-84.
Lo, C.-H., and Lee, C.-Y., 1994, ${ }^{40} \mathrm{Ar} /{ }^{39} \mathrm{Ar}$ method of $\mathrm{K}-\mathrm{Ar}$ age determination of geological samples using the Tsing-Hua Open-Pool (THOR) Reactor: Geological Society of China Journal, v. 37, p. 143-164.

Lovera, O. M., Richter, F. M., and Harrison, T. M., 1991, Diffusion domains determined by ${ }^{39} \mathrm{Ar}$ released during step heating: Journal of Geophysical Research, v. 96, p. 2057-2069.

Odin, G. S., and 35 collaborators, 1982, Interlaboratory standards for dating purposes, in Odin, G. S., ed., Numerical dating in stratigraphy: Chichester, United Kingdom, Wiley, p. 123-149.

Onstott, T. C., and Peacock, M. W., 1987, Argon retentivity of hornblendes: A field experiment in a slowly cooled metamorphic terrane: Geochimica et Cosmochimica Acta, v. 51, p. 2891-2903.

Onstott, T. C., Hall, C. M., and York, D., 1989, ${ }^{40} \mathrm{Ar} /{ }^{39} \mathrm{Ar}$ thermochronology of the Imataca Complex, Venezuela: Precambrian Research, v. 42 , p. $255-291$.

Peltzer, G., and Tapponnier, P., 1988, Formation and evolution of strike-slip faults, rifts, and basins during the India-Asia collision: An experimental approach: Journal of Geophysical Research, v. 93, p. 15085-15117.

Platt, J. P., and England, P. C., 1993, Convective removal of lithosphere beneath mountain belts: Thermal and mechanical consequence: American Journal of Science, v. 293, p. 307-336.

Schärer, U., Tapponnier, P., Lacassin, R., Leloup, P. H., Zhong, D., and Ji, S., 1990, Intraplate tectonics in Asia: A precise age for large-scale Miocene movement along the Ailao Shan-Red River shear zone, China: Earth and Planetary Science Letters, v. 97 , p. $65-77$.

Schärer, U., Zhang, L.-C., and Tapponnier, P., 1994, Duration of strike-slip movements in large shear zone: The Red River belt, China: Earth and Planetary Science Letters, v. 126, p. 379-397.

Tapponnier, P., Peltzer, G., Armijo, R., Le Dain, A.-Y., and Cobbold, P., 1982, Propagating extrusion tectonics in Asia: New insights from simple experiments with plasticine: Geology, v. 10, p. 611-616. Tapponnier, P., Lacassin, R., Leloup, P. H., Schärer, U., Zhou, D., Wu, H., Liu, X., Ji, S., Zhang, L., and Zhong, J., 1990, The Ailao Shan/Red River metamorphic belt: Tertiary left-lateral shear between Indochina and South China: Nature, v. 343, p. $431-437$.

Taylor, B., and Hayes, D. E., 1983, Origin and history of the South China Sea, in Hayes, D. E., ed., Tectonic and geologic evolution of Southeast Asian seas and islands, Part 2: American Geophysical Union Monograph 27, p. 23-56.

Manuscript received February 19, 1998

Revised manuscript received June 24, 1998

Manuscript accepted July 13, 1998 